\title{
Collaborative Networks to Provide Media Accessibility: the Potential of Social Subtitling
}

\author{
NoA TalavÁN \\ José JAVIER ÁVILA-CABRERA \\ Universidad Nacional de Educación a Distancia, UNED
}

Received: 28 September 2015 / Accepted: 29 January 2016

ISSN: 1697-7467

\begin{abstract}
Audiovisual products are becoming more and more accessible to all types of users. As far as audiovisual communication is concerned, nowadays a considerable number of audiovisual programs viewers can watch in Spain are usually made accessible by means of subtitles for the deaf and hard of hearing (SDH), audiodescription (AD) or sign language interpreting (SLI). In the context of the university, the actual need to make audiovisual products accessible to the whole community becomes pivotal, given the importance of addressing two major issues: firstly, meeting the needs of the deaf and hard of hearing by being able to access information via subtitles; and, secondly, producing subtitles for those not linguistically competent in the corresponding $\mathrm{L} 2$; AD and SLI are more complicated to implement in this setting, and that is why the present approach deals with subtitling alone. In particular, this paper delves into the results obtained from a social subtitling project, conducted in 2014 and implemented at the Universidad Nacional de Educación a Distancia (UNED), where volunteer students subtitled videos both individually and collaboratively so as to make them accessible to a wider audience. The analysis of the qualitative data gathered complements previous research in the field and sheds more light into the potential of social subtitling of audiovisual programs produced at the university so as to proceed to fruitful further research. Keywords: social subtitling, accessibility, distance learning, collaborative work.
\end{abstract}

Redes colaborativas para proporcionar accesibilidad: el potencial de la subtitulación social

RESUMEN: Cada vez son más los productos audiovisuales que se hacen accesibles para todo tipo de usuarios. En lo referente a la comunicación audiovisual, un número importante de programas audiovisuales que los telespectadores pueden ver hoy día en España son accesibles gracias a los subtítulos para sordos (SpS), la audiodescripción (AD) y la interpretación de lengua de signos (ILS). Dentro del contexto universitario, la disponibilidad de vídeos accesibles se convierte en una necesidad fundamental, dada la importancia de tratar dos aspectos primordiales: por un lado, cubrir las necesidades de personas con discapacidad auditiva proporcionándoles acceso a la información por medio de subtítulos; y, por el otro, crear subtítulos para aquellas personas que tengan carencias lingüísticas en la correspondiente L2. La AD y la ILS son modalidades más complicadas de implementar en el contexto universitario, y es por ello que este primer acercamiento se centra en subtitulación exclusivamente. En concreto, este artículo ahonda en los resultados obtenidos durante un proyecto de subtitulación social, llevado a cabo en 2014 e implementado en la Universidad Nacional de Educación a Distancia (UNED), donde estudiantes voluntarios subtitularon vídeos de modo tanto individual como colaborativo con el fin de hacerlos accesibles a un número mayor de usuarios. El análisis de los datos cualitativos recogidos complementa investigaciones previas 
y arroja más luz sobre las posibilidades de la subtitulación social de programas audiovisuales producidos en la universidad, abriendo el camino hacia un prometedor campo de investigación futuro.

Palabras clave: subtitulación social, accesibilidad, educación a distancia, trabajo colaborativo.

\section{INTRODUCTION}

Media accessibility is today a necessity considering the breakup of frontiers derived from the ever-growing media world generated by the Internet. The new media consumer society expects personalized access to audiovisual material at all levels. However, even if social awareness on accessibility needs is growing rapidly (Díaz-Cintas, 2013), the truth is there are still realms where real access is not covered given the lack of means. One of these settings is likely to be the university. The audiovisual production of this type of institutions is so vast (teachers' lectures, seminars, students' contributions, promotional videos, etc.), that the lack of human resources and economic budget often make accessibility a very challenging task to accomplish.

A potential solution to this problem could reside in non-professional subtitling, among other audiovisual translation (AVT) modes. This trend, also known as fansubbing in some contexts, is increasing day by day, and there is a growing number of volunteers who are not professional subtitlers but enjoy the task and want to share their work online for others to profit from it (Orrego-Carmona, 2015). This motivation and interest may be transferred to university students who could create subtitles for videos produced by their institutions and related with their field of expertise. They would be performing a social task while learning more about the corresponding subject. This would easily connect with and be enhanced by the benefits of the use of subtitling to improve foreign language skills, since volunteers would be practicing the foreign language while subtitling and so benefit from all the potential related advantages (Talaván, 2006, 2013).

We view this type of non-professional subtitling that provides accessibility in the university setting as a social task, in the line of websites such as TED (https://www.ted. com/), Amara (http://www.amara.org/es/) or Viki (https://www.viki.com/community), and that is why the term coined and used throughout this work will be social subtitling. In a previous experience, an assessment of the potential of social subtitling at the university was piloted (Talaván and Ávila-Cabrera, in press) and gave way to the present proposal, where a bigger number of students got involved in the social subtitling of a series of videos of their own choice in need of linguistic accessibility (that is, the transfer from L2 to L1 that makes a product accessible to a non-native speaker). The work of the subjects was monitored through observation in an online environment (where they also made an intensive use of forums and chats), since they were students at the Universidad Nacional de Educación a Distancia (Spanish National Open University, UNED). The results gathered have confirmed the conclusions derived from the aforementioned pilot study and positively complemented them, as will be later discussed, opening the door to further study in the field. 


\section{TheORETICAL BACKGROUND}

The field of amateur or non-professional subtitling -also known as fansubbing (DíazCintas and Muñoz-Sánchez, 2006)- has been receiving increasing attention in the last few years and two recent doctoral theses dealing with this topic (Massidda, 2013; OrregoCarmona, 2015) constitute good evidence of this matter. In fact, a good number of studies have been dealing with this phenomenon in the course of the last decade, and non-profit initiatives like Amara (https://amara.org/es/) and Viki (https://www.viki.com/community) for subtitling or The Rosetta Foundation (http://www.therosettafoundation.org/) and Translation Commons (http://trommons.org/) for non-professional translation in general accompany and reinforce this trend.

The vast technological advances of the last decades together with the ever-growing fan community (especially as far as TV shows are concerned) have enabled the rapid growth of this type of subtitling that implies both individual and collaborative work within a context where terms like community engagement and crowdsourcing can easily have a place. Today's participatory culture, where peer work and collective expertise and intelligence are becoming more and more trendy, is the perfect setting for volunteers to cover multilingual accessibility needs through amateur subtitling.

Although previous experiences of non-professional translation in general (Pérez-González and Susam-Saraeva, 2012; Zaidan and Callison-Burch, 2011) easily back-up the interest generated by amateur AVT (especially in the form of subtitling), the present theoretical review will focus on the latter, given its relevance for the study described below. Research on this specific area of non-professional subtitling (most commonly dealt with as fansubbing) dates back to 2005, where authors like Kayahara (2005) or Ferrer-Simó (2005) started to describe the origin (amateur subtitling of Japanese anime), influence, possibilities and potential effects of this practice. Díaz-Cintas and Muñoz-Sánchez (2006) also contributed to the description of this phenomenon, reflecting, at the same time, upon the ethics and legality of fansubs. From then on, other authors such as Pérez-González (2007a, 2007b, 2012a, 2012b), Bogucki (2009), O’Hagan (2009), Martínez García (2010), Lee (2011), Massidda (2013) or OrregoCarmona (2015) have highlighted the relevance of this practice through different studies.

While Pérez-González's articles (2007a, 2007b) emphasize the potential for propagation of fansubbing in the present multimodal and intersemiotic society, O'Hagan's work (2009) goes beyond fansubbing and describes the evolution from the fan translation phenomenon to crowdsourcing, introducing the concept of 'user-generated translation (UGT)', and concluding on the potential impact of "the unparallelled devotion of the otherwise untrained Internet crowd as translators" (ibid.:94) on the translation and localization industry. Both Bogucki (2009) and Martínez García (2010) discuss the quality of fansubs, the latter providing a thorough description of the collaborative networks and processes created and followed by fansubbers and ending on a positive note as far as improvement in quality is concerned. Lee (2011) analyses anime fansubs (that lay at the origin of this practice) in detail and concludes by claiming that fansubbing could somehow unsettle the global mediascape given the existence of multiple mediations within a particular cultural text. In addition, this author provides a new model of content distribution and organization based on voluntary work performed by consumers themselves. It is of relevant note for this paper the deep reflection and profound 
discussion on the epistemological, civic and even political implications of this phenomenon of participatory translation provided by Pérez-González (2012a, 2012b). He claims amateur subtitling to be somehow part of a movement of "cultural resistance against global capitalist structures and institutions, where volunteers often go beyond accuracy so as to play a part in the "audiovisual semiotic ensemble"" (2012b:335). This interpretation of non-professional subtitling is akin to the idea of social subtitling presented in this paper. Finally, the two aforementioned doctoral theses (Massidda, 2013; Orrego-Carmona, 2015) present a detailed description of fansubbing today, the former focusing on the analysis of the beliefs and practices of two online Italian communities and the latter describing the audience reception of fansubs, analyzed through eye-tracking techniques and questionnaires.

An element that is very often questioned when dealing with fansubbing is ethics and copyright issues. Luckily, social subtitling can be said to be safe in this regard, since volunteers contribute to making videos accessible whenever necessary (as far as the corresponding organization, website or institution is concerned) and no related economic profit whatsoever is supposed to exist; the subtitles are not necessarily commissioned by the organization but they are more than welcome, thereby highlighting the essence of social subtitling, which mainly lays on the social aspect on the task. Not many studies have so far reflected upon the possibilities of this volunteer AVT practice viewed as a social task of providing accessibility, but a few authors already advocate for the vast possibilities opened by this type of subtitling that goes beyond what we know as fansubbing. In the university setting (where most of these initiatives are taking place), Beaven et al. (2013) describe a related project undertaken at the Open University, in Great Britain. The project involved general volunteer translation of a Translation Massive Open Online Course, and many students collaborated in the subtitling of Open Educational Resources contained in the course. The conclusion of this experience points towards the possibilities of spreading these open translation models within the ever-growing world of open education. Another related experience, also in the university context, took place at our institution, the UNED (Rodrigo, 2015). In this case, cyber volunteers transcribed and subtitled video classes produced by teachers from various courses lectured in Spanish. The conclusion, in this case, points towards the potential of social work at the university and shows "the capacity of new technologies to promote social innovation and bring about citizen empowerment, fully accomplishing the goals of social accessibility" (ibid.:online).

Even the platform TED (https://www.ted.com/) has been the focus of research. A related reference on voluntary subtitling is the study on the motivational factors for becoming a volunteer subtitler (Cámara de la Fuente, 2015); this piece of research uses TED members as a reference (TED's statistics show more than 22,000 non-professional subtitlers registered in the platform) and provides relevant elements of discussion as far as the potential profile of people interested in this practice is concerned.

A final field of relevance to provide theoretical basis to the practice of social subtitling is the use of AVT to promote foreign language learning skills. The benefits of the different AVT modes used as didactic resources have already been highlighted by several authors (Bravo, 2008; Talaván, 2010; Borghetti, 2011; Díaz-Cintas, 2012; Talaván and RodríguezArancón, 2014b; Baños and Sokoli, 2015; among many others) and a good evidence of the potential advantages of this practice is the online platform ClipFlair (Sokoli, 2015). ClipFlair (clipflair.net) provides a free subtitler editor (with revoicing options available for dubbing 
and other voice-related activities) especially designed to use AVT to teach and learn foreign languages, as well as almost five hundred ready-made activities (different foreign languages, levels and ages are addressed).

Students involved in this type of didactic tasks, where subtitling is used as an active pedagogical resource, have most often claimed to have kept on subtitling outside the classroom (in a non-professional, fan-like mode) and are commonly willing to take part in similar experiences in the classroom or in online contexts (Incalcaterra McLoughlin and Lertola, 2014; Talaván and Rodríguez-Arancón, 2014a; Talaván and Ávila-Cabrera, 2015). Hence, they could easily become social subtitlers or even fansubbers one day. In fact, many amateur subtitlers do so partly because they feel they can improve their foreign language skills (Cámara de la Fuente, 2015), and this makes perfect sense if we think about all the potential benefits in terms of foreign language skills enhancement implied by this practice, in terms of oral comprehension, vocabulary acquisition, writing skills and many other related integrated language activities (Talaván, 2013).

In a context where the number of fansubbers and related organized communities, as well as the number of students that have the opportunity of using AVT to improve foreign language skills, is growing non-stop, the interest in voluntary subtitling, simply following the social momentum of the promotion of linguistic accessibility, is a clear and natural aftermath; in such a context, initiatives such as the one included in the present study have a good number of possibilities to succeed.

\section{The STUdy: PARTICIPANTS, ResourCeS AND PROCEDURES}

This study was undertaken in the course of the second semester of the 2013-2014 academic year at the UNED. The students (from a distance learning setting) who participated in this social subtitling project were third-year students of the degree in English Studies and they were all taking the course named Traducción de textos generales y literarios inglés-español (English-Spanish general and literary translation). Volunteers were gathered from this university course that has around 400 students registered every year and the total number of students who signed up for the initiative was 32. They were asked to register in Amara (http://www.amara.org/es/) and join Amara's Global Volunteer Community ${ }^{1}$ (http:// about.amara.org/volunteer/). Participants were asked to individually subtitle 4 videos each to then share the result to be collaboratively revised on Amara by their peers. Students had to choose the videos themselves (they had to deal with scientific or academic topics and be available on YouTube) and were asked to look for videos originally in English and lacking subtitles in Spanish. The subtitle editor contained in Amara was considered suitable for this task since it is very intuitive and has a good and easy to follow tutorial. At the end, once all videos (a total number of 128) were revised by peers and the links to the final subtitled products uploaded to the forums at the UNED virtual platform aLF (https://www.innova. uned.es/servicios/alf/), students were asked to write a report on the experience.

\footnotetext{
${ }^{1}$ Several volunteer teams in Amara (a project of the Participatory Culture Foundation), divided into different organizations, are in charge of making videos accessible for users all over the world.
} 
Hence, the main resources of the project were the UNED virtual platform aLF (that included the forums, the videoconference and the final report), Amara community, the subtitle editor, the questionnaires and the videos. The participants were familiar with the virtual platform because it was the one they had their regular courses on; a specific community was created just for the project so as to include all the necessary instructions as well as the exchanges with peers and teachers.

As far as the procedures are concerned, the project lasted two months. Students who registered for the project completed a pre questionnaire (http://tinyurl.com/om82gy8) where general information on the sample was gathered (students' profile and interests). Then, after registering in Amara, they were explained the basics regarding the use of this platform and they were invited to a videoconference on general subtitling matters by Professor Jorge DíazCintas. Thanks to this lecture, subjects were provided with an overview of the subtitling task for newcomers to this field. After this introduction, they were asked to select the first video and start subtitling using Amara or any of the recommended subtitle editors (regardless of their choice, the final subtitles file needed to be uploaded to Amara). Students were not given specific deadlines (they were free to organize their time to work at their own pace) but once each video was subtitled, they had to let their classmates and tutors know in the forum (aLF), so that they could provide revision cues (if needed). Students were also asked to pay attention to the forums so as to help their classmates out with questions and/or subtitles revision. Finally, once they finished translating, revising and uploading their subtitles, they had to write a final report on the experience, providing the links to their videos as well as a short comment on the experience (both as a subtitler and as a reviewer/collaborator). At the end, a videoconference, carried out through the AVIP videoconference tool (https:// www.intecca.uned.es/inteccainfo/), was organized to gather feedback on the experience and a post questionnaire (http://tinyurl.com/n9tmq6e) containing aspects that could provide data on the outcome of the project was completed by all the participants.

\section{Main Data ANd discussion}

The data gathered in this project offered qualitative information, gathered through the pre questionnaire, the discussions which took place on the platform forums, the assessment of the written reports, the post questionnaire and the final videoconference. As regards the outcomes of the project, it resulted not only in a good number of videos made linguistically accessible to a wider audience, but also in a series of benefits for participants in terms of translation and linguistic skills enhancement, all of which are to be discussed in the present section.

\subsection{Data analysis}

According to the data obtained from the pre questionnaire, most of the participants were female ( $72 \%$ vs. $28 \%$ males, as is usually the case with language-related studies) and aged 21-42 -although a few of them were between their late forties and early sixties. Almost all of them (93.75\%) had no previous subtitling experience -excluding one of them who was a fansubber and another one who had already subtitled a few video clips. Among the most 
recurrent reasons for participating in the project were willingness to learn how to subtitle, to learn translation strategies through the use of subtitles, to become a professional subtitler in the future and just for leisure.

As was already mentioned, the participants selected the videos on academic and scientific topics which were to be subtitled using Amara and Table 1 illustrates a small sample of them.

Table 1. Sample of subtitled videos.

\begin{tabular}{|l|l|}
\hline Title & Link \\
\hline $\begin{array}{l}\text { Video 1. Inside The Mind Of Austin } \\
\text { Carlile }\end{array}$ & $\begin{array}{l}\text { http://amara.org/es/videos/Whi5qDWRuSio/info/inside- } \\
\text { the-mind-of-austin-carlile/ }\end{array}$ \\
\hline $\begin{array}{l}\text { Video 2. Why do some people live } \\
\text { to 100? }\end{array}$ & $\begin{array}{l}\text { http://www.amara.org/fr/videos/zbeDTEk6gwX4/ } \\
\text { es/693244/ }\end{array}$ \\
\hline $\begin{array}{l}\text { Video 3. Who was the first human } \\
\text { ancestor? }\end{array}$ & $\begin{array}{l}\text { http://www.amara.org/es/videos/nL80WA6wrp7z/info/ } \\
\text { who-was-the-first-human-ancestor-instant-egghead-31/ }\end{array}$ \\
\hline $\begin{array}{l}\text { Video 4. What Is the Maillard Reac- } \\
\text { tion? }\end{array}$ & $\begin{array}{l}\text { http://www.amara.org/es/videos/wOGdi1mMxlGX/info/ } \\
\text { what-is-the-maillard-reaction-instant-egghead-44/ }\end{array}$ \\
\hline
\end{tabular}

Through observation and monitoring, which took place basically in the forums, we could verify that the first videos that were subtitled presented numerous mistakes which could be said to be typical of users who are not very familiar with this AVT mode: for example, line breaks which were not syntactically or semantically correct, excessive exposure of subtitles on screen, wrong use of punctuation, etc. Based on the feedback provided both by the observers and by their peers, improvements were made on the videos and subsequent subtitles became much better. Figure 1 includes snapshots from two of the actual videos which were subtitled in the course of the project.

Figure 1. Snapshot of subtitled videos.

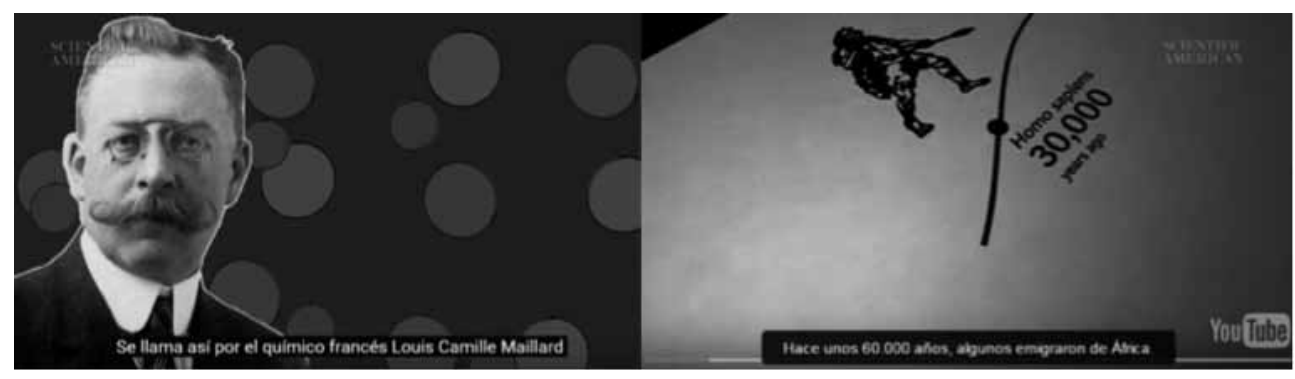

It is worth noting that the total number of participants who had enrolled in the project also finished it by accomplishing all the tasks proposed, which translates in an outstanding commitment to the project itself. A fact that can be reconfirmed by the analysis of the responses to the post questionnaire as well as the number of accesses to the virtual community (over $5,100)$ and its duration (more than 1,700 minutes) in the course of two months. As for the 
level of satisfaction with the learning outcomes, $90 \%$ of the participants accounts for those who asserted to be very satisfied $(48.50 \%)$ and also completely satisfied $(42.40 \%)$. From a pedagogical point of view, once again a considerably high percentage of the participants did recognize to have learnt foreign language skills thanks to the social subtitling experience; this perception confirms the power of subtitling to learn foreign languages, as was anticipated above. Figure 2 illustrates what the participants considered to have been boosted in this regard.

Figure 2. Improvement of skills according to post questionnaire.

\section{Learning outcomes}

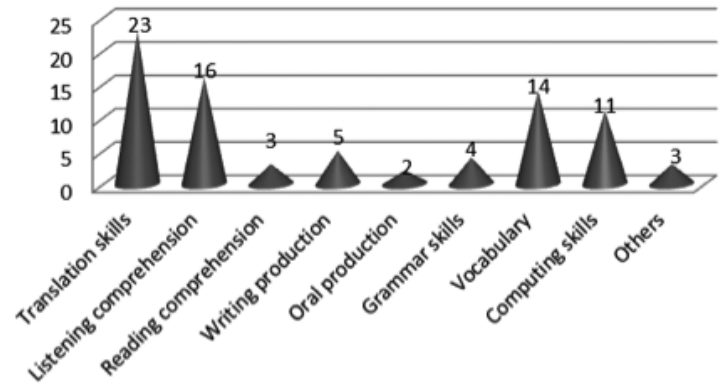

Based on the above information, it becomes clear that translation skills (69.70\%), listening comprehension $(48.50 \%)$ and vocabulary $(42.40 \%)$ were the areas where the participants felt a bigger enhancement in L2 learning terms. As for listening comprehension and vocabulary, dealing with videos in L2 undoubtedly helps improve the former because of the exposure to oral input. In addition, as subtitling entails condensing and looking for the most appropriate terms and to be able to transfer the gist of the message, this practice results in a fruitful pedagogical approach on lexical acquisition. Regarding translation skills, Figure 3 below shows how such skills can be improved when subtitling videos within a non-professional context, since $97 \%$ of participants (answer selection range from 4 to 6 ) agreed that the experience allowed them to enhance their English to Spanish translation competence.

Figure 3. Translation skills according to post questionnaire. eng>spa translation skills enchancement

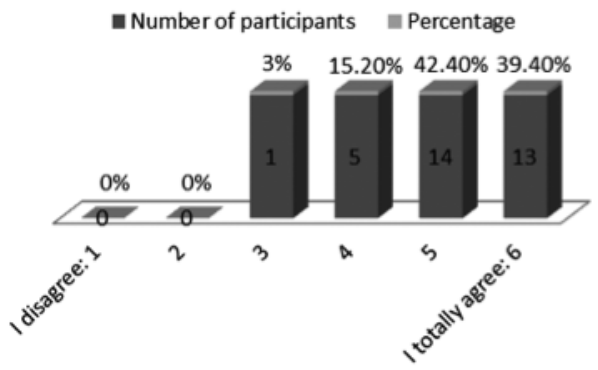


The power of subtitling as a tool to enhance general translation skills had already been pointed out by previous researchers in the field (Rundle, 2000; Neves, 2004; Incalcaterra McLoughlin, 2009; De Marco, 2011, among others) and these results can be said to confirm this fact.

Other results permitted us to elucidate that apart from having experienced how to subtitle with Amara (a subtitling platform which $45.80 \%$ found useful and easy to use), the participants were intrigued and motivated enough to explore other subtitling programs and platforms such as Subtitle Workshop, DiviXLand Media Subtitler, ClipFlair and Aegisub, among others. Finally, attention was paid to the participants' opinions on whether they would participate in other similar social subtitling projects with no reward involved whatsoever in future years: more than a quarter would definitely be willing to do it and almost half of them would consider it.

\subsection{Discussion}

The main goal of the present project -making videos linguistically accessible to users as part of a social subtitling initiative- which entails carrying out non-lucrative activities, was fulfilled in a very fruitful way given the successful promotion of these tasks within a distance learning setting at university, which easily fits with the online universal context we currently live in. The participants played a leading role in the project, as non-professional or social subtitlers, and they became more familiar with the subtitling practice as well as improved a number of translation and linguistic related skills.

Special interest can be observed when, within a distance learning context, the number of participants who firstly enrolled the project finish all the assignments inasmuch as in this type of projects the fact that some participants abandon it is not uncommon. We could therefore assert that subtitling provides students with both attractive and motivating activities.

Given the overall number of videos subtitled (128) and the limited or inexistent previous experience of students, technical problems and errors in the production of subtitles were expected (at least in the first videos), as has been already mentioned. In view of the discussion which took place in the forums, some of the students' more recurrent mistakes, which would be unacceptable in professional environments, were the use of three and even four-line subtitles (the standard length is one or two lines per subtitle), incorrect segmentations, too long subtitle durations on screen, wrong punctuation marks or sentences lacking syntactic and/or semantic correction. Thanks to the students' monitoring via aLF, they could fix many of the aforementioned mistakes before uploading their final subtitled version to Amara. In any case, since it was a social subtitling initiative geared towards making videos accessible by non-professional subtitlers, it was expected that subtitles could present flaws.

The students' active participation was monitored at all times and the space where most communication between students and researchers took place was the forums in aLF. More than 9,000 accesses to the forums prove how active communication and completion of tasks were, including discussion on the subtitles produced, the peer-review process, as well as feedback on their performance, report submission and assessment, and the final videoconference (via the platform intecca). In addition, the time spent on the forums is an indicator of the participants' enthusiasm, willingness to produce quality subtitles and to monitor their peers' work. 
The final video conference permitted the researchers to obtain more direct insights into the way the participants felt about their performance, team work and results. A more direct and synchronous communication between students and teachers can usually lead to clearer and more direct feedback. In this particular case, the participants expressed their satisfaction emanated from their work in the videos that were made accessible for all Amara users. Some of the most interesting comments included reflections on the fact that subtitles can be addictive and how difficult condensing the message can be (particularly when dealing with fast dialogue exchanges). Some participants even compared learning translation through books on literary and general translation to doing so by producing subtitles, which turns the activity into 'an entertaining, dynamic and good practice' that could even give way to future training in professional subtitling for some of them.

The students' final reports were very well written and presented thorough information related to clip selection, revision process and peer-review. The marks obtained from the assessment of the reports were rather good (an average of 8.9) and the final comments on the experience confirmed, once again, the encouraging outcomes resulting from it. ${ }^{2}$ The majority of the students showed interest in continuing the task, be it as a social subtitler, fansubber or even as a professional subtitler, as can be derived from some of the following notes and reflections: 'seeing my translations pop up on the screen, under the speaker, and knowing that people who didn't speak English could use my subtitles to understand the videos was quite exciting'; 'When I finish this degree, I might investigate more into this world and the job opportunities available'; 'I really enjoyed doing it, so when possible, I'll try to keep collaborating with Amara'; 'the great army of amateur subtitlers we can find nowadays has helped us have availability of translations for the increasing amount of videos on the Internet, and has also made evident the important (and often undervalued) task of professional translators'; 'I am really glad I have had the opportunity to participate in this project, I have learned a lot and have gained lots of useful tips for my future job'.

It is of note to observe that one of the main goals of this project was to make videos accessible through a subtitling virtual platform (Amara) that grows every day thanks to their users' altruistic multilingual subtitles production. These efforts could be easily transferred to the UNED media library (which contains audiovisual material mainly produced by lecturers, see CanalUNED, https://canal.uned.es) where, apart from contributing to the creation of more accessible clips, future volunteers might be able to improve their translation and language-related skills in different ways.

\section{Conclusion}

This paper has explored the possibilities of undertaking a social subtitling project at the university thanks to the work of a group of students who subtitled English video clips lacking subtitles in Spanish within Amara. Such an initiative opens the doors for future nonprofessional subtitling research, especially in a Higher Education context, where the vast amount of videos produced at these institutions keeps growing, but accessibility options are

\footnotetext{
${ }^{2}$ It should be noted that these marks had no reflection whatsoever in the final mark of the subject, given the voluntary nature of the project.
} 
rarely considered (most often because there is no room for AVT budget). In a globalized setting with ample room for providing any user with accessible audiovisual content, these types of initiatives are always necessary.

The present social subtitling project has fundamentally resorted to the participants tasks materialized in 128 videos made accessible through a subtitling platform, Amara, which continues expanding more and more thanks to its users' non-lucrative subtitles production. On the grounds of qualitative data, we have been able to count on a variety of information gathered through pre and post questionnaires, forum discussions, a final videoconference and the participants' final written reports. All in all, the creation of subtitles, aimed at bringing about accessibility, has brought to the fore a thought-provoking number of benefits including translation and linguistic skills enhancement. Thus, the results emerged from this experiment invite researchers to look further into the potential of social subtitling.

Given the positive conclusions obtained in this study, the next step has been the creation of a wiki space to upload all the UNED videos lacking subtitles: i-AMICO (http://iamico.wikispaces.com, Initiative for Multilingual and Multimodal Access to Information and Communication). Created in an attempt to invite alumni to register and provide subtitles to the the university videos, available in the media library (CanalUNED), i-AMICO promotes the creation of collaboration networks, AVT learning and sharing of information on realted seminars, conferences, courses and the like. Further data gathered from this experience will be discussed in subsequent contributions.

The recent but ever-growing developments in terms of accessibility in audiovisual mass media in Europe is a fact that is greatly benefiting viewers (both sensory and cognitively impaired and people who do not know the language in which a specific program is available). However, to obtain total audiovisual access for all and to guarantee a full understanding of the concept of accessibility in our society, more steps need to be taken. Social subtitling may not be the direct solution to this situation, but it is clearly helpful in terms of expanding the social awareness on this particular need, while it provides access to audiovisual material that would stay inaccessible otherwise.

\section{Acknowledgements}

We would like to express our most sincere gratitude to Tomás Costal, a UNED grant holder, for his thorough involvement in the project and all his support to the participants on general, technical and subtitling issues.

\section{REFERENCES}

Baños, R. and Sokoli, S. (2015). "Learning foreign languages with ClipFlair: Using captioning and revoicing activities to increase students' motivation and engagement", in K. Borthwick, E. Corradini and A. Dickens (eds.), 10 Years of the LLAS Elearning Symposium: Case Studies in Good Practice. Dublin and Voillans: Research-publishing.net, 203-213.

Beaven, T., Comas-Quinn, A., Mirjam Hauck, B. and Lewis, T. (2013). "The Open Translation MOOC: Creating online communities to transcend linguistic barriers", in Journal of Interactive Media in Education, 3: 18. 
Bogucki, L. (2009). "Amateur subtitling on the Internet", in J. Díaz-Cintas and G. Anderman (eds.), Audiovisual translation: Language transfer on screen. New York: Palgrave Macmillan, 49-57.

Borghetti, C. (2011). "Intercultural learning through subtitling: The cultural studies approach", in L. Incalcaterra McLoughlin, M. Biscio and M.Á. Ní Mhainnín (eds.), Audiovisual Translation Subtitles and Subtitling. Theory and Practice. Bern: Peter Lang, 111-137.

Bravo, C. (2008). Putting the Reader in the Picture: Screen Translation and Foreign-Language Learning (Doctoral dissertation, Universitat Rovira i Virgili), available from http://www. tesisenred.net/bitstream/handle/10803/8771/Condhino.pdf?sequence=1, accessed 10 July, 2015.

Cámara de la Fuente, L. (2015). "Motivation to collaboration in TED Open Translation Project", in Int. J. We Based Communities, 11, 2: 210-229.

De Marco, M. (2011). "Bringing gender into the subtitling classroom", in L. Incalcaterra McLoughlin, M. Biscio and M.Á. Ní Mhainnín (eds.), Audiovisual Translation Subtitles and Subtitling. Theory and Practice. Bern: Peter Lang, 139-155.

Díaz Cintas, J. (2012). "Los subtítulos y la subtitulación en la clase de lengua extranjera", in Abehache, Revista da Associação Brasileira de Hispanistas, 2, 3: 95-114, available from http://www.hispanistas.org.br/arquivos/revistas/sumario/revista3/95-114.pdf, accessed 15 July, 2015.

Díaz Cintas, J. (2013). "La accesibilidad a los medios de comunicación audiovisual a través del subtitulado y de la audiodescripción", in Cooperación y diálogo, 157-180, available from http://cvc.cervantes.es/lengua/esletra/pdf/04/020_diaz.pdf, accessed 10 July, 2015.

Díaz Cintas, J. and Muñoz Sánchez, P. (2006). "Fansubs: Audiovisual translation in an amateur environment", in JoSTrans. The Journal of Specialised Translation, 6, 1: 37-52, available from http://www.jostrans.org/issue06/art_diaz_munoz.php, accessed $10 \mathrm{July,} 2015$.

Ferrer-Simó, M.R. (2005). "Fansubs y scanlations: la influencia del aficionado en los criterios profesionales", in Puentes, 6: 27-43.

Incalcaterra McLoughlin, L. (2009). "Subtitles in translators' training: A model of analysis", in Romance Studies, 27, 3: 174-185.

Incalcaterra McLoughlin, L. and Lertola, J. (2011). "Learn through subtitling: Subtitling as an aid to language learning”, in L. Incalcaterra McLoughlin, M. Biscio and M.A. Ní Mhainnín (eds.), Audiovisual Translation. Subtitles and Subtitling. Oxford: Peter Lang, 243-263.

Incalcaterra McLoughlin, L. and Lertola, J. (2014). "Audiovisual translation in second language acquisition. Integrating subtitling in the foreign-language curriculum", in The Interpreter and Translator Trainer, 8, 1: 70-83.

Kayahara, M. (2005). "The digital revolution: DVD technology and the possibilities for audiovisual translation", in JoSTrans. The Journal of Specialised Translation 3: 64-74, available from www.jostrans.org/issue03/articles/kayahara.pdf, accessed 15 July, 2015.

Kayahara, M. (2005). "The digital revolution: DVD technology and the possibilities for audiovisual translation", in JoSTrans. The Journal of Specialised Translation 3: 64-74, available from www.jostrans.org/issue03/articles/kayahara.pdf, accessed 15 July, 2015.

Lee, H.K. (2011). "Participatory media fandom: A case study of anime fansubbing", in Media, Culture \& Society, 33, 8, 1131-1147.

Martínez García, E.M. (2010). "Los fansubs: el caso de traducciones (no tan) amateur", in Tonos digital: Revista electrónica de estudios filológicos, 20, 4, available from https://www. um.es/tonosdigital/znum20/secciones/monotonos-los_fansubs.htm, accessed 10 July, 2015.

Massidda, S. (2013). The Italian Fansubbing Phenomenon. (Doctoral dissertation, Università degli Studi di Sassari), available from http://eprints.uniss.it/8183/1/Massidda_S_Italian_Fansubbing_phenomenon.pdf, accessed 10 July, 2015. 
Massidda, S. (2015). Audiovisual Translation in the Digital Age: The Italian Fansubbing Phenomenon. Hampshire and New York: Palgrave Macmillan.

Neves, J. (2004). "Language awareness through training in subtitling", in P. Orero (ed.), Topics in Audiovisual Translation. Amsterdam: John Benjamins, 127-139.

O’Hagan, M. (2009). "Evolution of user-generated translation: Fansubs, translation hacking and crowdsourcing", in Journal of Internationalisation and Localisation, 1, 1: 94-121.

Orrego Carmona, J.D. (2015). The Reception of (Non)Professional Subtitling: A Descriptive Approach. (Doctoral dissertation, Universitat Rovira i Virgili), available from http://www. tesisenred.net/bitstream/handle/10803/306439/Tesi\%20Jeffersson.pdf?sequence $=1$, accessed 15 July, 2015.

Pérez-González, L. (2007a). "Intervention in new amateur subtitling cultures: A multimodal account", in Linguistica Antverpiensia, New Series-Themes in Translation Studies 6, available from https://lans-tts.uantwerpen.be/index.php/LANS-TTS/article/view/180/111, accessed 10 July, 2015.

Pérez-González, L. (2007b). "Fansubbing anime: Insights into the 'butterfly effect' of globalisation on audiovisual translation", in Perspectives, 14, 4: 260-277.

Pérez-González, L. (2012a). "Amateur subtitling as immaterial labour in digital media culture: An emerging paradigm of civic engagement", in Convergence: The International Journal of Research into New Media Technologies, 19, 2: 157-175.

Pérez-González, L. (2012b). "Amateur subtitling and the pragmatics of spectatorial subjectivity", in Language and Intercultural Communication, 12, 4: 335-352.

Pérez-González, L. and Susam-Saraeva, Ş. (2012). "Non-professionals translating and interpreting: Participatory and engaged perspectives", in The Translator, 18, 2: 149-165.

Rodrigo, C. (2015). "Students social accessibility to improve quality of multimedia resources in a blended-learning environment", in B.R. Jones (ed.), Blended Learning: Student Perceptions, Emerging Practices and Effectiveness. New York: Nova Science Publishers, 12.

Rundle, C. (2000). "Using subtitles to teach translation", in R.M. Bollettieri Bosinelli, C. Heiss, M. Soffritti and S. Bernardini (eds.), La traduzione multimediale: Quale traduzione per quale testo? Bologna: CLUEB, 167- 181.

Sokoli, S. (2015) "Foreign language learning through interactive revoicing and captioning of clips", in Y. Gambier, A. Caimi and C. Mariotti (eds.), Subtitles and Language Learning. Bern: Peter Lang, 127-148.

Talaván, N. (2006). "Using subtitles to enhance foreign language learning", in Porta Linguarum: revista internacional de didáctica de las lenguas extranjeras, 6: 41-52, available from http://www.ugr.es/ portalin/articulos/PL_numero6/talavan.pdf, accessed 7 July, 2015.

Talaván, N. (2010). "Subtitling as a task and subtitles as support: Pedagogical applications", in J. Díaz-Cintas, A. Matamala and J. Neves (eds.), New Insights into Audiovisual Translation and Media Accessibility. Amsterdam: Rodopi, 285-299.

Talaván, N. (2013). La subtitulación en el aprendizaje de lenguas extranjeras. Barcelona: Octaedro.

Talaván, N. and Rodríguez-Arancón, P. (2014a). "The use of reverse subtitling as an online collaborative language learning tool", in The Interpreter and Translator Trainer, 8, 1: 84101, available from http://www.tandfonline.com/doi/pdf/10.1080/1750399X.2014.908559, accessed 10 July, 2015.

Talaván, N. and Rodríguez-Arancón, P. (2014b). "The use of interlingual subtitling to improve listening comprehension skills in advanced EFL students", in B. Garzelli and M. Baldo (eds.), Subtitling and Intercultural Communication. European Languages and Beyond. Pisa: InterLinguistica, ETS, 273-288. 
Talaván, N. and Ávila-Cabrera, J.J. (2015). "First Insights into the combination of dubbing and subtitling as L2 didactic tools", in Y. Gambier, A. Caimi and C. Mariotti (eds.), Subtitles and Language Learning. Bern: Peter Lang, 149-172.

Talaván, N. and Ávila-Cabrera, J.J. (in press). "Social subtitling: Providing the university community with accessible videos", in D.O. Orrego-Carmona and Y. Lee (eds.), Non-Professional Subtitling. Newcastle upon Tyne: Cambridge Scholars Publishing.

Zaidan, O.F. and Callison-Burch, C. (2011). "Crowdsourcing translation: Professional quality from non-professionals", in O.F. Zaidan and C. Callison-Burch (eds.), Paper proceedings of the 49th Annual Meeting of the Association for Computational Linguistics: Human Language Technologies, 1: 1220-1229. Portland, Oregon, USA, 19-24 June, 2011. 